\title{
高誘電損失材料の誘電特性の新測定法とその応用
}

\author{
新井智一・一条 文二郎 \\ 静岡大学工学部 浜松市城北 3-5-1
}

(昭和 46 年 8 月 5 日 受付)

\section{A New Method of Measuring Dielectric Property of Very-High-Loss Materials and Its Applications}

\author{
Tomokazu Arai and Bunjiro Ichijo \\ (Faculty of Engineering, Shizuoka University, Hamamatus) \\ (Received August 5, 1971)
}

This paper presents a circuit system functioning as a capacitance and resistance meter suitable for very-high-loss materials with a wide range of application in various fields of scientific research and industrial operation.

The system for the capacitance meter has two measuring arms; thus, it requires a pair of specimens. An apparent positive reactance variation caused by the low resistance of the specimen placed in one arm is cancelled by the apparent negative reactance variation in the other arm. Therefore, the error due to a large shunt conductance is eliminated from the capacitance measurement.

The system for the resistance meter is a resonance circuit having a very-high $Q$ coil and a differential condenser with a series resistor which acts variable resistance at radio frequencies. The resistance variation caused by inserting the resistance of the specimen into the capacitance measuring circuit is detected as a change in the output of the amplifier circuit. This value is measured by the diferential condenser and the series resistor.

The minimum equivalent parallel resistance of the specimen to be measured reaches as low as $50 \Omega$ and the measuring range of the capacitance is about $0.1 \sim 1200 \mathrm{pF}$ at $2 \mathrm{MHz}$.

As an application of this circuit system, the dielectric property of 'wet paper, 'textile fibers and wood is measured. From the result of the measurement, it becomes clear that the capacitance of woods is proportioned to the moisture content in a region of free water. And the capacitance deviation due to the moisture content is proportioned to the apparent density of wet wood, but not affected by the kind of wood.

\section{1. まえがき}

各種材料の物性を調べる方法の 1 つである誘電率法 は，比較的簡単な装置によって測定を行ならことがで きるので古くから用いられている. この装置の代表的 なものとしては Qメータやキャパシタンス・ブリッジ がある、ところで，たとえばQメータについてみると， この装置は Q值が非常に高い材料の静電容量の測定は

† 電気学会全国大会で発表 (昭 $46 \cdot 3$ )
容易であるが，その損失の測定は不可能となる，逆に $\mathrm{Q}$ 值の低い材料, すなわち, 電気伝導性の良い材料や 半導体材料汶しては, 共振曲線が平坦になってしま い, 共振点をみつけることができなくなり，材料の静 電容量すなわち比誘電率を求めることも，また損失を 測定することも不可能になる.キャパシタンス・ブリ ッジについても Qメータの場合と同じようなことがい 兄る. 以上のようにQ值の低い高誘電損失材料につい てその誘電特性を測定することは非常に困難なことで 
ある. そのためと思われるが電解質の希薄水溶液の比 誘電率を古くから多くの人たちによって測定されてい るが，その結果はまちまちで中には矛盾するようなも のもみられる ${ }^{1)}$. したがって高誘電損失材料を対象と する誘電特性測定回路の開発については物性研究者は もとよりであるが，応用研究にたずさわっている者に とっても待ち望まれている課題といえる. 最近に和け る研究成果としては，測定試料に直列と並列に静電容 量を接続して誘電分散を怙こさせて比誘電率と誘電損 失とを求めている神吉らの研究2)，市販のブリッジに 新しい検出器を付加した S.E. Young らの研究 ${ }^{3)} ， 4$ 電極零位法を用いた H.P.Schwan らの研究4), 変成 器ブリッジを用いた D. Rosen ら，特よび M. A. Seitz らの研究占),6多あるが，筆者らは共振回路を用いた新 しい測定法を開発したので，原理・特性特よびその応 用例比ついて報告する。

\section{2. 測定原理および方法}

1.で述べたように，外国に括けるこの種の測定回 路はほと九ど変成器ブリッジの改良によっている。こ れははん用の変成器ブリッジが市販されて和り, 容易 に入手できるためと思わ机る。しかるにわが国では， 変成器ブリッジはそれはど普及されていないため，ブ リッジを製作するとなると変成器でいきづまってしま 5. その点筆者らの回路は初期の調整汇多少手数を要 するが，使われている部品は簡単なものばかりで，製 作が容易である点が特長といえる．以下順に測定回路 の詳細を述べる。

Fig. 1 は測定回路の概略図であって, 図の $\mathrm{AB}$ か ら左側の amp. II 除く部分が高誘電損失材料の静電 容量測定部であり, $A B$ から右側の部分拈よび amp. II が等価並列抵抗測定部である.

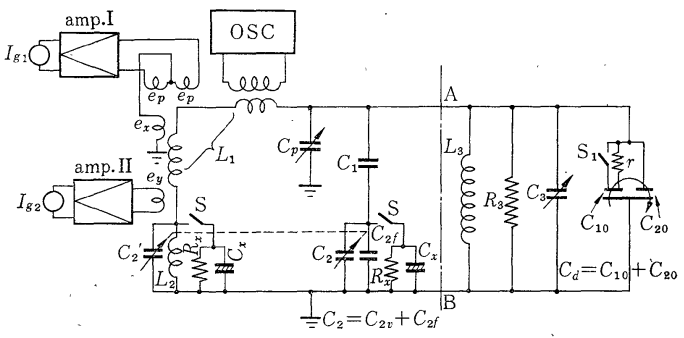

Fig. 1 Measuring circuit

\section{1 静電容量測定部}

前報7)に扣いて高誘電損失材料を測定対象とした静 電容量（以下容量と略記）測定回路について一部を発 表してあるので必要限度の事項のみを述べる。図にお いて OSC は高周波発振器, $L_{1}-L_{2}-C_{1}-C_{2}-C_{p}$ は直”列
共振回路, $C_{2 v}$ と $C_{2}{ }^{\prime}$ は標準可変空気コンデンサで歯 車をかいして連動するようになって抢り，ダイヤル1 目盛当たりの $C_{2 v}$ と $C_{2}{ }^{\prime}$ の容量変化は正確に等しく なるようにしてある.

回路が電源周波数に共振したとき, 電圧 $e_{x}$ と $e_{p}$ との間の位相差は $90^{\circ}$ となり, 高感度の位相検波增幅 器 amp. I の出力指示計 $I_{g_{1}}$ は零点を示す.

測定する試料 $\left(R_{x}, C_{x}\right)$ は $C_{2}$ と $C_{2}{ }^{\prime}$ とにそれぞれ 並列飞接続する。しかるときは指示計 $I_{g_{1}}$ が振れるか ら， $C_{2}$ と $C_{2}{ }^{\prime}$ を減少させて再び $I_{g 1}$ の振れを零にす れば, そのときの標準コンデンサの容量変化 $\Delta C_{2}=$ $\Delta C_{2}{ }^{\prime}=C_{x}$ から未知容量を求めることがでさる.

このようにして測定した容量值は等価並列抵抗 $R_{x}$ の影響を受けないようにすることができる。それには 回路の構成にあたって,

$$
\begin{array}{ll}
L_{e} /\left(L_{1}+L_{2}\right)=C_{1} / C_{2}\left(1+C_{p} / C_{e}\right) & (1) \\
& \omega^{2} L_{e} C_{2}\left(1+C_{1} / 2 C_{2}\right) \simeq 1 \\
& C_{p} \simeq 3 C_{1} / 4\left(1+C_{2} / C_{1}\right) \\
\text { ただし, } & L_{e}=L_{2} /\left(1-\omega^{2} L_{2} C_{2}{ }^{\prime}\right), \\
& C_{e}=C_{1} C_{2} /\left(C_{1}+C_{2}\right), \omega: \text { 電源の角周波数 }
\end{array}
$$

なる条件が満足されるようにすればよい。

\section{$2 \cdot 2$ 等価並列抵抗測定部}

これは $L_{3}-C_{3}-C_{d}$ の並列共振回路とピックアップ コイル $e_{y}$ 特よび差動增幅器 amp. II から構成されて いる. $R_{3}$ はコイル $L_{3}$ の等価並列抵抗であっって, こ の值は非常に高くなるようにコイルを作るようにする。 $C_{3}$ は可変空気コンデンサであり， $C_{d}$ は差動コンデン サである. $C_{d}$ の一方の極板側には抵抗器 $r$ をとう入 乙て高周波可変抵抗器8) として動作させる.

いまスイッチSを閉じて試料 $\left(R_{x}, C_{x}\right)$ を測定回路 飞接続した場合, $\mathrm{AB}$ から左側をみた等価並列抵抗 $R_{p}^{\prime}$ は,

$$
R_{p}{ }^{\prime}=R_{x} / 2 \cdot\left(1+C_{2} / C_{1}\right)^{2}
$$

となる。

つぎに $\mathrm{S}$ 開き， $\mathrm{AB}$ から右側をみた等価並列抵抗 $R_{p}^{\prime \prime}$ は,

$$
\begin{aligned}
R_{p}{ }^{\prime \prime} & =R_{3} /\left(1+\omega^{2} C_{10}{ }^{2} r R_{3}\right) \\
\text { いま, } \omega^{2} C_{10}{ }^{2} r R_{3} & \gg 1 \text { とすれば, } \\
R_{p}{ }^{\prime \prime} & =1 / \omega^{2} C_{10}{ }^{2} r
\end{aligned}
$$

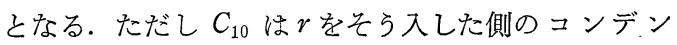
サの容量とする。

したがって，Sを閉じ（ $\mathrm{S}_{1}$ も同じ）たときの $I_{g_{2}}$ の振れを読みとり， $\mathrm{S}$ 開いて $と$ と $C_{10}$ とを調整し，

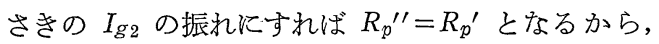
試料の $R_{x}$ は,

$$
R_{x}=2 / \omega^{2} C_{10}{ }^{2} r\left(1+C_{2} / C_{1}\right)^{2}
$$


より求められる.

\section{3. 測定回路の構成および特性}

\section{$3 \cdot 1$ 構 成}

測定回路の使用周波数範囲は一般に使われているQ メータ,と同じような範囲が可能であるが，製作の容易 さから固定周波数の $2 \mathrm{MHz}$ で使光るように試作した. コイル $L_{1}, L_{2}$ はステアタイト製ボビンにホルマール 線を密着巻きにして作り, 自己インダクタンスの值は $L_{1}=14.7 \mu \mathrm{H}, L_{e}=1.48 \mu \mathrm{H}$ といらょうに約 $10: 1$ V なるように決めた．コンデンサ $C_{1}, C_{2}$ としては可変 空気コンデンサ怙よびスチロールコンデンサを用い， 多少の調整は可変空気コンデンサで行なった． $C_{1}$ の 容量值は約 $400 \mathrm{pF}$ として(1)式の条件を満足するよ らな $C_{2}$ の容量值は約 $4000 \mathrm{pF}$ となったが，ほぼこ の値で回路は正常に作動した．標準コンデンサの $C_{2}{ }^{\prime}$, $C_{2 v}$ は $0 \sim 100 \mathrm{pF}$ の可変空気コンデンサと固定容量 のスチロールコンデンサとを併用した．これは既製の 大容量の可変コンデンサがなかったためで， $C_{x}$ は $0.1 \sim 1200 \mathrm{pF}$ まで測定可能である.

$L_{3}$ のコイルはQの高いるのほどよいが，試作した ものは直径 $80 \mathrm{~mm} \phi$, 長さ $150 \mathrm{~mm}$ のステアタイト 製ボビンに巻線直径 $1.6 \mathrm{~mm} \phi$ のホルマール線 ッチ $0.7 \mathrm{~mm}$ の間隔巻きに 55 回巻いたるのである. このインダクタンスは $115 \mu \mathrm{H}, R_{3}$ は約 $630 \mathrm{k} \Omega, Q$ は 370 でめった. $C_{d}$ はステアタイト製の可変空気 ンデンサ $30 \mathrm{pF}$ を 2 個組み合わせて作った.

$C_{x}$ を測定するための検出用 amp. I を Fig. 2(a) に， $R_{x}$ を湘定するための検出用 amp. II を Fig. 2 (b) 示す.
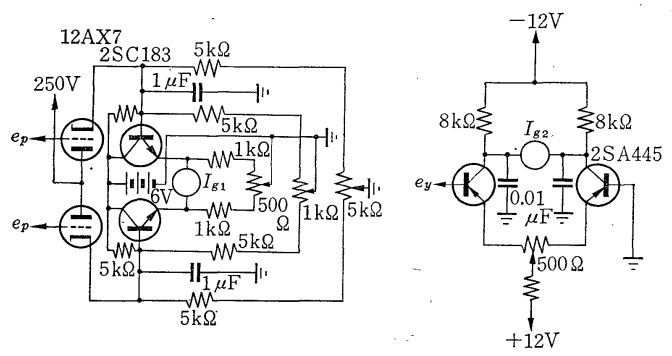

(a) circuit of amp. I

(b) circuit of amp. II Fig. 2 Detector circuit

\section{2 特 性}

Fig. 3 以試料と乙て炭素皮膜抵抗器を用い，その 抵抗值 $R_{x}$ を $0.05 \sim 100 \mathrm{k} \Omega$ 末で変化したときの標 準コンデンサの容量偏差 $\Delta C_{x}$ (試料が接続されない ときを0）を実験により求めたものであり， $C_{2}{ }^{\prime}$ をパ ラメータとして示してある. 炭素皮膜抵抗器自体の容

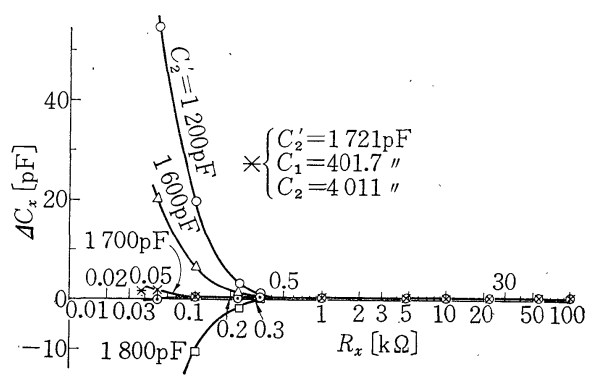

Fig. 3 Relationship between $\Delta C_{x}$ and $R_{x}$

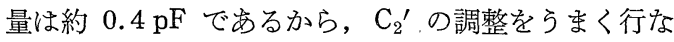
えば $\mathrm{C}_{2}{ }^{\prime}=1721 \mathrm{pF}$ の例にみられるように $R_{x}=50 \Omega$ 以上であるならば， $R_{x}$ の值無関係汇試料の $C_{x}$ を 測定することができる.

この測定法は 1 組の試料を同時に $L_{2}$ と $C_{2}$ 、接続 しなければならないが，そのため 1 組の試料が同じで なければ，それにとるなら誤差が生ずることが予測さ れるこれを実験によって調べたのが Fig. 4 である.

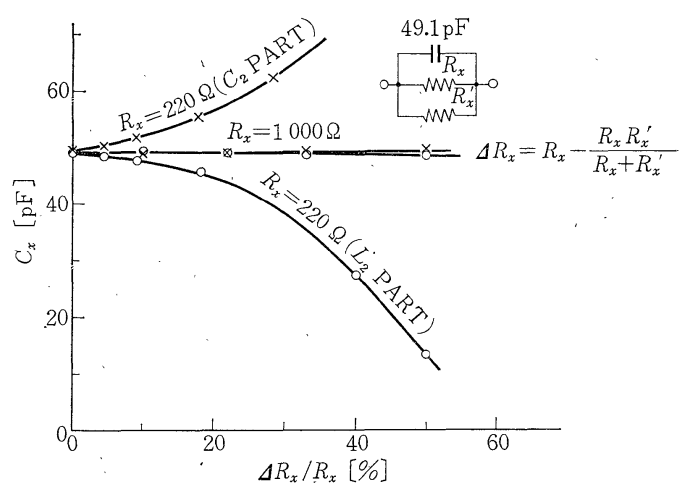

Fig. 4 Relationship between $C_{x}$ and $\Delta R_{x} / R_{x}$

図から明らかなように， $R_{x}$ が $1000 \Omega$ 以上であれば 1 組の $R_{x}$ の值が $30 \%$ 程度相異してもとの影響はほ とんど認められないが， $R_{x}$ が $500 \Omega$ 以下になるとそ の值が低くなるほど著しくなる。図では $R_{x}=220 \Omega$ の例が示して市り， $C_{2}$ 側倿続される試料の等価並 列抵抗が大きい場合は容量值が見掛け上增加し, 反対 飞 $L_{2}$ 側に接続される試料の等価並列抵抗のほうが大 きい場合は容量值が見掛け上減少する。しかしながら， 容量增加や減少は汪とんど対称的になるから，このよ らな試料の測定にあたっては測定を 2 回くりか兄せば よい。すなわ方，試料の接続を $L_{2}$ 側と $C_{2}$ 側と郝互 いに取り換えて行ない，2回の測定から得られた $C_{x 1}$ と $C_{x 2}$ の平均をとれば, これが $C_{x}$ の真值を示すこ とになる。

静電容量測定部の容量感度 $\Delta I_{g} / \Delta C_{x}$ と $R_{x}$ との関 


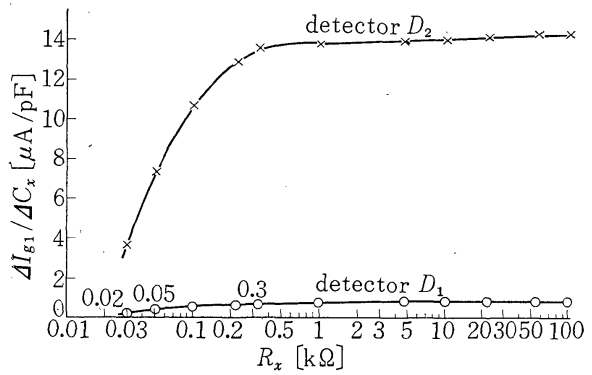

Fig. 5 Relationship between $\Delta \operatorname{Ig}_{1} / \Delta C_{x}$ and $R_{x}$

係を Fig. 5 亿示す。 $12 \mathrm{AX} 7$ 1 段の久の場合 (detector $D_{1}$ ) は最大でる $0.8 \mu \mathrm{A} / \mathrm{pF}$ の感度しかないが， Fig. 2 (a) に示したよらにトランジスタ 2SC 183 を 付加した場合 (detector $D_{2}$ ) は最大感度約 $14.2 \mu \mathrm{A} /$ $\mathrm{pF}$ となり, $\Delta C_{x}=0.1 \mathrm{pF}$ の検出が容易である.

等価並列抵抗測定部の検出には $e_{y}$ の電圧をダイオ ードで検波して直流電流計（mA）で読久取る場合と， Fig. 2（b)の上うな差動堌幅器を用いた場合とでは

Fig. 6 に示すような相異がある。すなわち， $L_{1}-L_{2}$ -

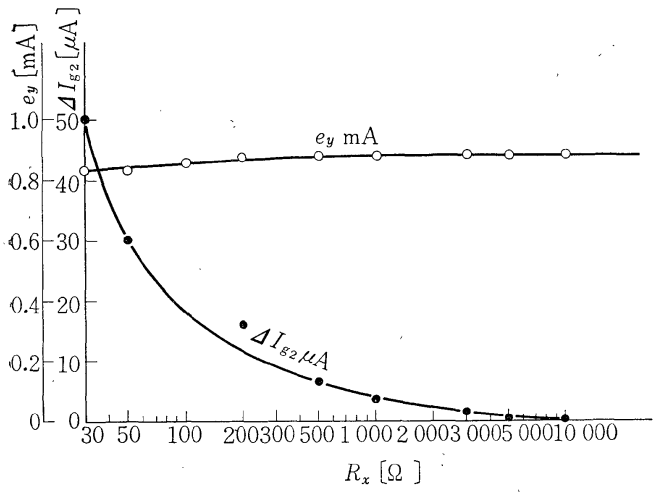

Fig. 6 Difference of detctor for $e_{y}$

$C_{1}-C_{2}-C_{p}$ で構成される直列共振回路の Q Q中低いため $e_{y}$ を直接電流計で読み取るのは不適当とい光る。し たがって，amp. II を用いて $R_{x}$ のそう入にともなう 直列共振回路の $\mathrm{Q}$ 值の变化分の久女マイク口電流計 ( $\mu \mathrm{A})$ の読み $I_{g_{2}}$ として取り出すことが有効である. また $I_{g_{2}}$ がわかれば, 高周波可変抵抗器である差動コ ンデンサの容量值 $C_{10}$ と $r$ とより(6)式によって $R_{x}$ の值を求めることができる. Fig. 7 は $r$ をパラメー タとして $I_{g 2}$ と差動コンデンサ・ダイヤル目盛 $C_{10}$ との関係を示したものである.な渗参考のために $R_{x}$ の值を求めた結果を右側の縦軸に示した．図から明ら かなように， $R_{x}$ の值が比較的高い場合，すなわち $I_{g_{2}}$ の振れが少ないときは，rの値の低いものを用い， 逆に $R_{x}$ の值が低い場合，すなわち $I_{g_{2}}$ の振れが大

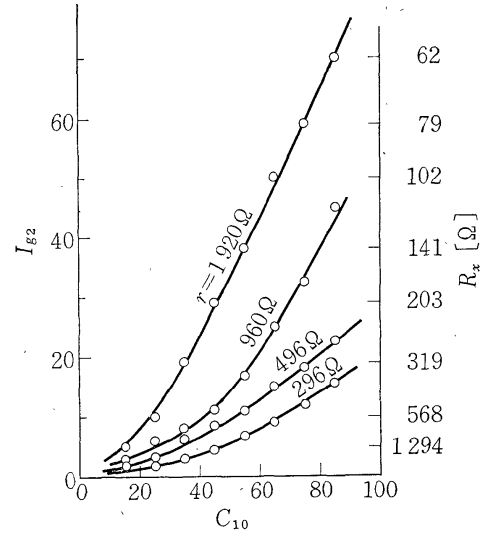

Fig. 7 Characteristics of differential condensor

きいときは，rの值の高いものを用いた活うが精度よ く測定できる.

静電容量測定部の検出電流 $I_{g_{1}}$ と等価並列抵抗測定 部の検出電流 $I_{g_{2}}$ との相互作用を調べたのが Fig. 8

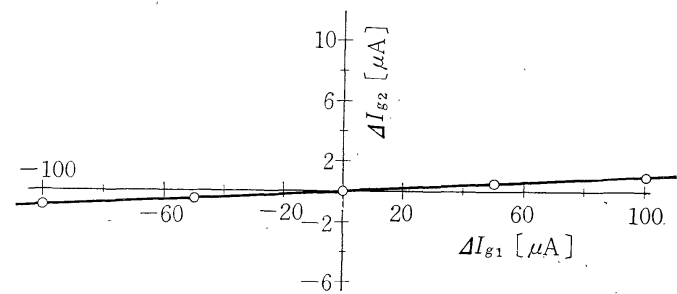

Fig. 8 Interaction of $\Delta I g_{1}$ and $\Delta I g_{2}$

である．実際の測定では，零位法であるから $I_{g_{1}}=0$ にするが，わざと $\pm 100 \mu \mathrm{A}$ の振れを与えても， $I_{g 2}$ は $\pm 1 \mu A$ の変化しか起きていないから， $I_{g_{1}}$ と $I_{g_{2}}$ との相互作用は無視してさしつか充ないと思う。

4. 応

\section{$4 \cdot 1$ 電解質溶液の誘電特性}

$\mathrm{NaCl}, \mathrm{KCl}, \mathrm{LiCl}, \mathrm{BaCl}_{2}, \mathrm{MgSO}_{4}, \mathrm{RbCl}, \mathrm{CuSO}_{4}$ などの希薄水溶液の誘電特性を 1 組の同心 円筒電極 (外径 $2 r_{1}=8 \mathrm{~mm} \phi$, 内径 $2 r_{2}=45 \mathrm{~mm} \phi$, 高さ $l=$ $11 \mathrm{~mm}$ ) を用いて測定した。 その結果の一例を Fig. 9 呿よび Fig. 10 亿示す。溶液濃度としては $4 \times 10^{-5}$

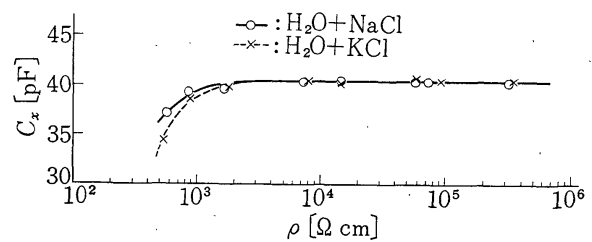

Fig. 9 Relationship between $\mathrm{C}_{x}$ and $\rho$ 


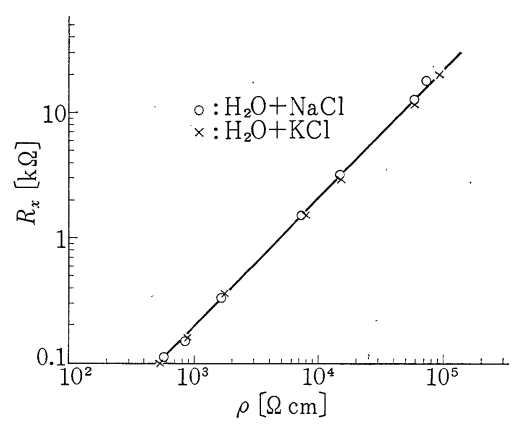

Fig. 10 Relationship between $R_{x}$ and $\rho$

〜 $1.5 \times 10^{-2}$ (規定) の範囲であった。 また横·軸の抵 抗率 $\rho$ は東垔電波(株)製の CM-1 DB 形数字式電導度 計と電導度セル CG-201 PL とを用いて導電率を測定 し，その逆数を示したものである.

Fig. 9 からは蒸溜水の $\rho=3.5 \times 10^{5} \Omega \mathrm{cm}$ に対する 容量と水溶液の $\rho=2 \times 10^{3} \Omega \mathrm{cm}$ までの容量とは同じ であったが， $\rho$ の值がさらに小さくなると，両水溶液 の容量は減少した.すなわち, 水の比誘電率に比べ電 解質の希薄水溶液の比誘電率はある濃度以上になると 減少することを示している．このよらな現象は Sach 効果によって説明することができる. Fig. 10 からは, $R_{x}$ と $\rho$ の関係が $45^{\circ}$ の直線となって特り，この範囲 では $R_{x}=\rho / 2 \pi l \cdot \log r_{2} / r_{1}$ の関係が満足される.

\section{$4 \cdot 2$ 高含水材料の静電容量}

この実験には 1 組の円環格子 電 極 ${ }^{9}$ (Fig. 11 (a) 参照）を用いたので予備実験として，この電極を底と する容器を作り, この容器の中に比誘電率 $\varepsilon_{s}$ の異な

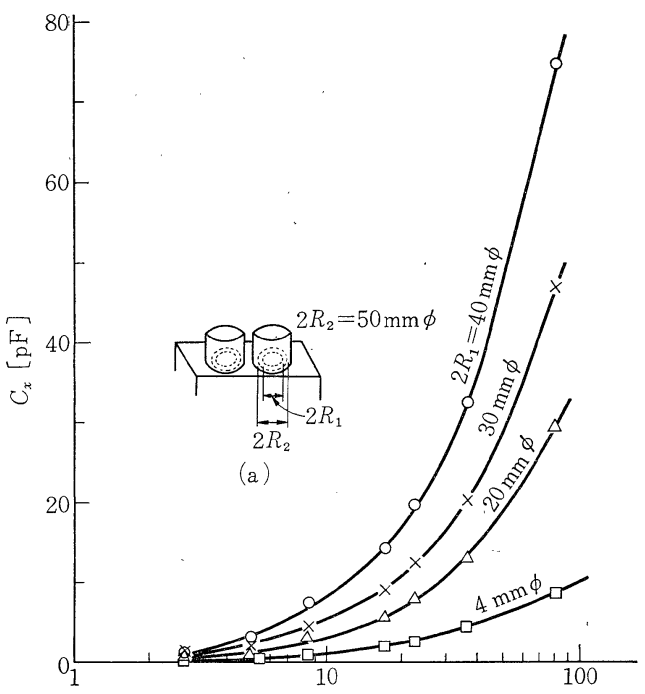

(b)

$\varepsilon_{s}$

Fig. 11 Relationship between $C_{x}$ and $\varepsilon_{s}$
る溶媒を入れて容量 $C_{x}$ と $\varepsilon_{s}$ との関係を調べた. こ れを図示したのが Fig. 11 (b) である.な沶内部電 極の外径 $2 R_{1}$ をパラメータとした. これらから明ら かなように $C_{x}$ と $\varepsilon_{s}$ とは比例している。すなおち， 以下の実験に使えることがわかった。

$\mathbf{4} \cdot \mathbf{2} \cdot 1$ 紙 紙の含水にともなら見掛けの比誘電 率変化を測定することは, 紙の物理的構造を調べるこ とや紙の比誘電率変化より水分を電気的に測定する誘 電率形電気水分計の水分測定範囲を明確にすることな どのために必要なことがらである。ところで水分が $20 \%$ 以上の高含水域になると, 含水紙の等価並列抵抗 值が低くなるため，一般の容量測定回路では抵抗值の 影響が大さくなり，含水紙の容量を正確に測定するこ とは困難である. そのため高含水域に和ける容量と水 分との関係を示す結果はほとんど発表されていない.

筆者らは薄紙12枚を重ねたもの（薄いと厚さの变化 が大きいため) を試料として，さきの円環格子電極を 用い, $C_{x}$ と湿量基準の水分 $M^{\prime}$ との関係を求めたも のを Fig. 12 に示した. な特 $W_{0}$ は絶乾重量, $W^{\prime}$ は

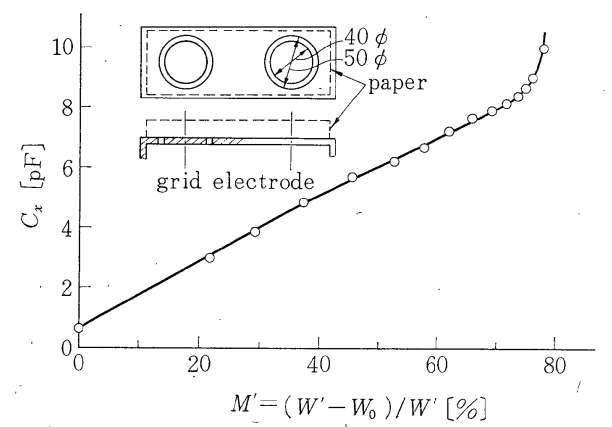

Fig. 12 Relationship between $C_{x}$ and $M^{\prime}$ with grid electrode for paper

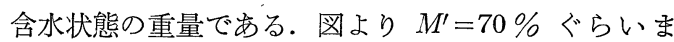
で $C_{x}$ は $M^{\prime}$ に比例している.このような関係につ いては, 岸ら ${ }^{10)}$ が織布について含水率と見掛け誘電率 との関係を乾量基準の水分 $M$ を使って考察して扣り， $M=0 \sim 20 \%$ の範团内では理論式と実験とが一致する ことを発表している. かように材料, 水分範囲は相異 するが岸らの考方方を拡張すれば Fig. 12 の実験結 果を説明することができる.な伺同じ薄紙を4 枚重ね てQメータ用の平行板電極で測定した例を Fig. 13 に示した. この場合の $C_{x}$ および $R_{x}$ の測定は複合

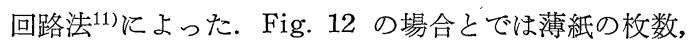
電極の構造などが異なるため紙の見掛けの比誘電率 $\varepsilon_{s}$ と $M^{\prime}$ との関係に多少の相異が認められる.

$4 \cdot 2 \cdot 2$ 織 布 織布の含水状態に捈ける誘電特 性は紙の場合と同じょらな傾向を示すので省略するが, 


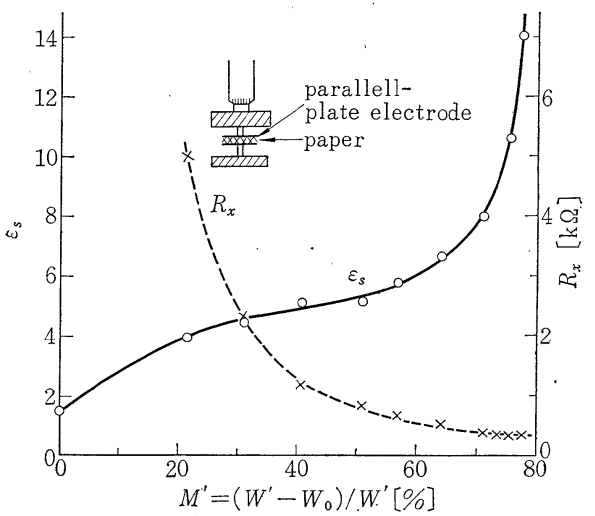

Fig. 13 Relationship between $\varepsilon_{s}, R_{x}$ and $M^{\prime}$ with parallel-plate electrode for paper

染色などに関連する予備実験について述べる。すなわ ら木綿やポプリン（テトロン $65 \%$ ，綿 $35 \%$ ）を種々 の濃度の希薄電解質溶液に浸漬させた後, ローラで一 定の水分にしぼったものの容量を測定した. Fig. 14

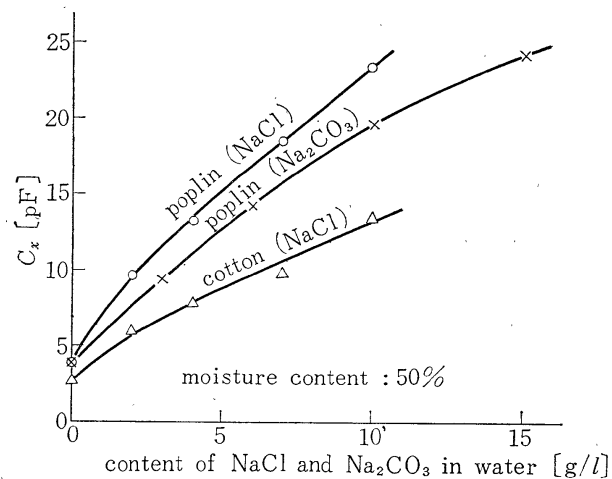

Fig. 14 Relationship between $C_{x}$ and content of $\mathrm{NaCl}$ and $\mathrm{Na}_{2} \mathrm{CO}_{3}$ in water for textile fibers

は容量を縱軸に, 電解質の濃度を横軸に示したもので ある．同じポプリンでも電解質によって容量值は異な り，また同じ電解質でる材質によって相異している. な和純水を含んだ織布の容量值にくらべ，電解質溶液 そ浸漬した織布の方が容量値は大きく，実験の範囲内 では濃度が大きい汪ど容量値は大きくなっている，溶 液の濃度としては Fig. 9 の場合よりも大きな濃度で 西るから，水溶液の比誘電率は水の 80.9 上りは小さ な值になっていると思われるが，それにるかかわらず， これらの水溶液に浸漬した織布の容量值が大きいのは, 水溶液の浸透圧が大きくなって，織布中の空気の部分 が少なくなるためと思われる。

$4 \cdot 2 \cdot 3$ 木 材 含水木材の誘電特性については, 紙や織布などにくらべて木材の密度は大きいから，と くに高含水域に括けるデータは非常に少ない，実験に
使った木材はすぎ，ひのき，ひめこまつ，かつら，特 よびラワンで大きさがたて $65 \mathrm{~mm}$, 横 $150 \mathrm{~mm}$, 厚 さ $20 \mathrm{~mm}$ のものについて $C_{x}$ と $M$ との関係を調べ, その結果を Fig. 15 に示した. 図から明らかなよう 飞，材質によって $C_{x}-M$ 曲線は相異しているが，傾 向としては $M$ の増加にともなって $C_{x}$ は単調に増加 している.

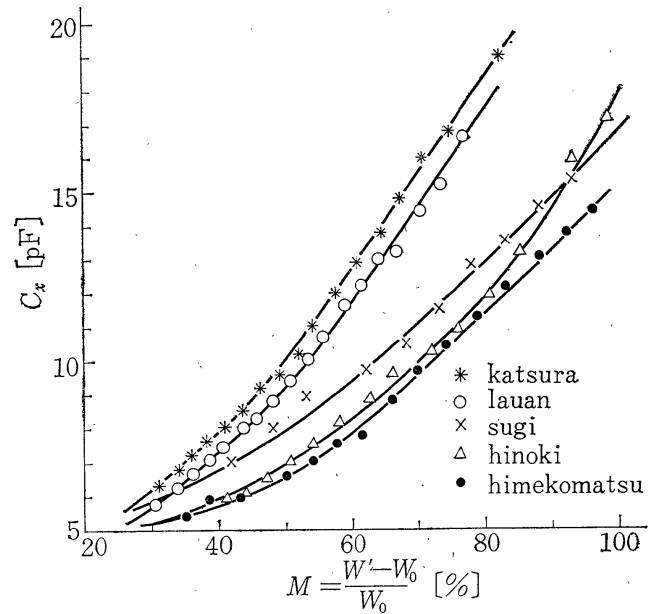

Fig. 15 Relationship between $C_{x}$ and $M$ for woods

低含水域（水分 $20 \%$ 以下）飞挌将る木材の誘電特 性については上村の研究 ${ }^{12}$ があり, そのうちの比誘電 率については著しい異方性を示すことや比重の影響が

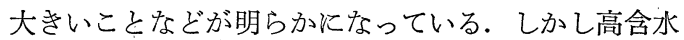
域になれば木材中の水の存在状態が変わるので, 低含 水域に拈ける考方方を適用することはできないと思わ れる. 以下では，この問題に対し巨視的な立場から考 察した．木材を緘維質と空気との混合系とみなしこ の混合系に水分を与兄た場合，水分が混合系に吸収さ れるものとすれば，木材の比誘電率と水分との関係は 次の近似式で表わされる ${ }^{13)}$.

$$
\varepsilon_{s}-\varepsilon_{s 0}=K M
$$

ただし， $M:$ 水分 [\%]， $K$ : 定数， $\varepsilon_{s}:$ 水分 $M$ 飞 特ける木材の見掛けの比誘電率， $\varepsilon_{s 0}: M=0$ 飞和け る木材の見掛秄の比誘電率.

したがって，M そ和ける木材の容量を $C_{x}$, 密度を $d_{w}, M=0$ に护的る木材の容量を $C_{x 0}$, 密度を $d_{0}$ と し，含水にともなう体積変化を無視すれば，

$$
C_{x}-C_{x 0}=K_{1} d_{w} / d_{0}-K_{1}
$$

となる，ただし， $K_{1}$ は定数とする。

(8)式から $C_{x}-C_{x 0}$ と $d_{w}$ とは比例している. そ こで Fig. 15 を書き改めて Fig. 16 を作った。 図の パラメータは木材の全乾密度 $d_{0}$ であり, 各曲線はほ 


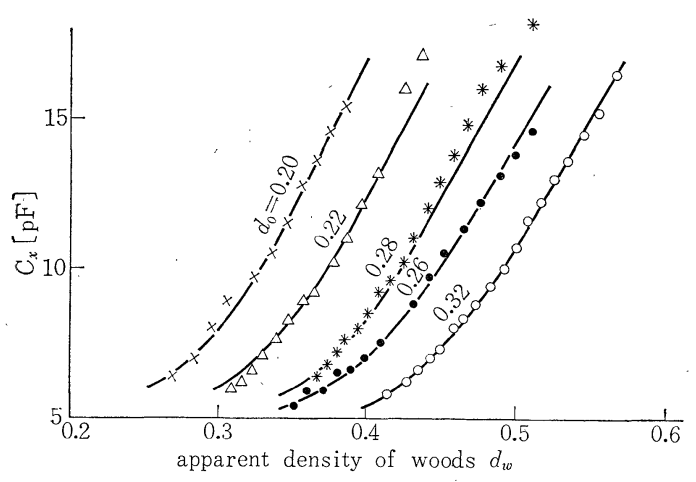

Fig. 16 Relationship between $C_{x}$ and $d_{w}$ for woods

涪平行している. このことは実験結果が定性的には (8)式の関係を満足していることになる。しかし $K_{1}$ ひいてはKは木材であれば材質あるいは $d_{0}$ によらな いと仮定したが，このことは実験結果に適合していな い. したがって $K_{1}$ は単なる定数ではなく $d_{0}$ の関数 $K_{1}\left(d_{0}\right)$ としなければならない。 また実测值から $K_{1}\left(d_{0}\right) / d_{0} \simeq 99\left[\mathrm{pF} \cdot \mathrm{cm}^{3} / \mathrm{g}\right]$ という值が得られ，これ は材質に無関係な一定值となった. これらのことから， 誘電率形電気水分計を校正するには $d_{0}$ による補正を 行なえばほぼ十分といえると思う。

\section{5.あとがき}

本測定法は回路構成が簡単であり，操作も容易であ るにもかかわらず, 零位法なので測定精度も高い。た た 1 組の試料を必要とするが，それら 1 組の試料の不 均一性による容量測定誤差は容易に取り除くことがで きる. 周波数 $2 \mathrm{MHz}$ に括方方測定範囲は静電容量值 が約 $0.1 \sim 1200 \mathrm{pF}$ ，等価並列抵抗值が約 $50 \sim 1500 \Omega$ である。

この装置の応用として電解質希薄水溶液の誘電特性 执よび紙，織布，木材などの高含水域に特ける静電容
量と水分との関係を明らかにした.

終わりに，実験に協力された飯尾元秀技官，菱藤電 機(株)河本 満君, 図面の作成に協力された短期大学 部学生森下義明君に感謝する.

\section{参考 文 献}

1) 岡 小天: 誘電体論, 191 (1954-岩波書店)

2）神吉ら：電気伝導のある物質の誘電率および誘電損失 を測定する一つの方法, 東北大学科学計測研究所報告, $15,2-3,115 / 124$ (1966)

3) S.E. Young \& E.H. Grant : Measurement of Permittivity of Some Biological Solutions at Freque ncies Below $1 \mathrm{MHz}$, J. Sci. Instrum., Series 2, 1, 4, 429/432 (1968)

4) H.P.Schwan \& C.D. Ferris : Four-Electrode Null Techniques for Impedance Measurement with High Resolution, Rev. Sci. Instr., 39-4, 418/485 (1968)

5) D. Rosen et al. : Radio Frequency Measurement of the Dielectric Constant of Conducting Liquids with $\tan \delta$ up to 500 , J. Sci. Instrum., Series 2, 2-1, 22/28 (1969)

6) M.A.Seitz et al. : A Technique for Determining the Dielectric Behavior of High Conductivity Materials, Rev. Sci. Instr., 40-6, 826/829 (1969)

7) B. Ichijo \& T. Arai : A New Method of Measuring Dielectric Property of Very-High-Loss Materials at High Frequencies, IEEE Tran. Instrumentation and Measurement, IM-19-1, 73/77 (1970)

8）一条・熊谷: 差動蓄電器を用いた高周波可変抵抗器の 原理ならびにその応用に就て, 理化学研 究所彙報, 21-7, 677/715 (1942)

9）新井・一条：置換法による粒体中の水分の誘電的測定, 計測自動制御学会論文集，3-1，54/61 (1967)

10）岸・三野：織布の含有水分率と見掛誘電率との関係に ついて, 応用物理, 26-8，347/350 (1957)

11）一条・新井: 半導体の誘電率, 損失角の新測定法につ いて, 電気学会雑誌, 74-786, 263/270 (1954)

12）上村：誘電率による木材含水率の測定に関する基礎的 研究，林業試験所研究報告，119 号，95/172 (1960)

13）新井：コイル電極を用いた粉，粒体の静電容量測定と その応用, 電気学会雑誌, 90-3，449/458 (1970) 